\title{
Kiat Menangkal Bahaya Hoax Dari Internet Terhadap Anak-Anak
}

\author{
Ni Made Sulastri, Dewi Rayani, Fitri Astutik. \\ Dosen Universitas Pendidikan Mandalika \\ nimadesulastri@,ikipmataram.ac.id
}

\begin{abstract}
Community service is aimed at increasing the knowledge and abilities of guardians of students and families in preventing the dangers of hoaxes from the internet to children. This is based on several observations that find indications of most parents or families in the current era of human life and activities of parents, teenagers and even children. Internet becomes one of the interests because all can be obtained with unlimited distance, the internet is always present in everyday life, even children seem to have been sedated with the internet. If we look at activities on the internet, especially on social media, it is not uncommon to find hoak information, the dangers of hoak information if it cannot be prevented or prevented it will be detrimental and can damage human morale. Parents' routines and activities are sometimes an obstacle in dealing with the dangers of hoak in children. Feeling that the impact of hoak information is very detrimental, so it is necessary to take care to prevent the dangers of hoak from the internet on children.
\end{abstract}

Abstrak; Kegiatan pengabdian pada masyarakat ini bertujuan untuk meningkatkan pengetahuan dan kemampuan wali murid serta keluarga dalam menangkal bahaya hoax dari internet terhadap anak-anak. Hal ini didasarkan beberapa pengamatan yang menemukan indikasi kebanyakan orang tua atau keluarga di era sekarang ini kehidupan dan aktifitas manusia dari orang tua, remaja dan bahkan anak-anak. Internet menjadi salah satu kepentingan karena semua dapat diperoleh dengan jarak yang tidak terbatas, internet selalu hadir dalam kehidupan sehari-hari, bahkan anak-anak sepertinya telah terbius dengan internet. Jika kita melihat aktivitas di internet terutama di sosial media, tidak jarang kita menemukan informasi-informasi hoak, bahaya informasi hoak tersebut jika tidak dapat ditangkal atau dicegah maka akan dapat merugikan serta dapat merusak moral manusia. Rutinitas dan kesibukan orang tua terkadang menjadi kendala dalam menangani bahaya hoak pada anak-anak. Merasa apabila dampak yang ditimbulkan dari informasi hoak tersebut sangat merugikan, sehingga dirasa perlu untuk dilakukan penanganan untuk menangkal bahaya hoak dari internet terhadap anak-anak.

\section{Kata Kunci : bahaya hoak, internet, anak-anak}

\section{PENDAHULUAN}

Internet menjadi salah satu kebutuhan untuk manusia saat ini, hal ini karena memang segalanya berhubungan dengan internet. Bukan hanya untuk hiburan, internet juga kini bisa digunakan menjadi salah satu media pembelajaran, pekerjaan dan banyak hal lainnya. Dengan kebutuhan yang semakin kompleks dan internet mempermudah semua hal itu, maka internet menjadi kebutuhan manusia jaman now.Untuk mendapatkan internet, saat ini merupakan hal yang sangat mudah. Ini berbeda dengan beberapa tahun lalu, dimana internet masih menjadi barang langka dan juga masih sangat mahal. Saat ini, semua orang tampaknya hampir memiliki smartphone, dan peralatan elektronik lainnya untuk mengakses internet bukan hanya di daerah perkotaan, namun juga di daerahdaerah.

Pertumbuhan internet di Indonesia memang berkembang sangat pesat, dan pertumbuhan ini diprediksi masih akan tumbuh pada beberapa tahun ke depan. Seiring dengan berkembangnya internet bahkan dari orang dewasa, remaja bahkan anak-anak semua membutuhkan internet. Dimanapun Anda berada, kini internet menjadi suatu kebutuhan yang sangat pokok. Banyak hal yang bisa kita pelajari dari internet, apalagi dari zaman ke zaman internet semakin canggih dari segi penggunaannya. 
Pada era digital ini, internet sangat berpengaruh pada kehidupan, manusia tidak perlu lagi bersusah payah mencari informasi dengan media cetak seperti koran dan majalah. Mesin pencari yang menjadi sebuah wadah dalam melakukan sebuah informasi, misalnya e-mail, e-learning, e-business, ebook, e-library, dan masih banyak lagi. Bisa di peroleh dengan internet.

Dari berbagai manfaat internet tersebut, terkadang tidak semua berita yang ada dapat dibenarkan pemberitaannya, oleh karena itu jika kita tidak dapat menggunakan internet secara bijak, maka tidak dapat dipungkiri internet juga akan dapat menimbulakan dampak negatif bagi manusia terutama bagi anak-anak, karena orang dewasa perlu bertanggung jawab untuk memfasilitasi dan mengawasi penggunaan internet tersebut agar anak tidak terpengaruh terhadap berita hoak dari internet. Rutinitas dan kesibukan orang tua terkadang menjadi kendala dalam menangani bahaya hoak pada anak-anak. Merasa apabila dampak yang ditimbulkan dari informasi hoak tersebut sangat merugikan, sehingga dirasa perlu untuk dilakukan penanganan untuk menangkal bahaya hoak dari internet terhadap anak-anak.

\section{STRATEGI DAN TARGET LUARAN}

Target dan luaran yang diharapkan dari kegiatan Pengabdian pada Masyarakat ini, khususnya bagi orang tua dan masyarakat Desa Rempung Kabupaten Lombok Timur adalah:

1. Para orang tua lebih memahami dan memiliki pengetahuan tentang cara menangkal berita hoak dari internet terhadap anak-anak.

2. Anak-anak dapat menggunakan internet dengan bijak agar tidak terpengaruh berita hoak dari internet.

Manfaat yang didapat dari pengabdian ini adalah menumbuhkan kesadaran dari masyarakat (orang tua) di desa Rempung kabupaten Lombok Timur tentang pentingnya pengetahuan menangkal hoak dari internet.

\section{METODE PELAKSANAAN}

Metode dalam pelaksanaan program pengabdian pada masyarakat ini adalah dalam bentuk penyuluhan/edukasi. Materi-materi yang dipresentasikan dalam pelatihan ini memperhatikan dan mempertimbangkan aspek relevansi (kesesuaian) dan berupaya mengakomodir kebutuhan akan pengetahuan dan keterampilan dan upaya pemecahan masalah yang dihadapi oleh para wali murid di Desa Rempung kabupaten Lombok Timur. Adapun deskripsi ringkasan terkait dengan pelaksanaan kegiatan ini dimulai dengan melakukan koordinasi dengan Tim PPM antar dosen untuk menyiapkan berbagai kebutuhan dan mekanisme kegiatan penyuluhan yang akan diselenggarakan. Selanjutnya tim PPM melakukan koordinasi dengan pengelola desa Rempung kabupaten Lombok Timur dalam rangka menyamakan persepsi terkait dengan teknis pelaksanaan kegiatan. Koordinasi dilakukan dengan melakukan pertemuan di lokasi sekaligus mengadakan diskusi dan observasi terkait dengan tempat pelaksanaan kegiatan penyuluhan/edukasi. Selanjutnya tim PPM mengembangkan berbagai materi yang akan disampaikan bagi peserta selama mengikuti kegiatan edukasi.

\section{HASIL KEGIATAN}

Pelaksanaan kegiatan penyuluhan pendidikan bagi keluarga tentang "Kiat Menangkal Bahaya Hoax Dari Internet Terhadap Anak-Anak" berlangsung pada hari Kamis, 5 September 2019 bertempat di Balai Desa Rempung Kabupaten Lombok Timur. Peserta yang mengikuti kegiatan berjumlah 30 orang.

Respon dari peserta terkait dengan kegiatan pengabdian ini sangat positif dan mendukung dengan baik, hal ini terindikasi dari peserta yang aktif (partisipatif) dalam mengikuti dan merespon proses kegiatan Selain itu, peserta yang sebagian besar orang tua yang memiliki anak ini cukup memiliki curiosity (rasa ingin tahu) yang tinggi dan antusias selama proses penyampaian materi. Selama proses pelatihan, banyak topik-topik (bahan) materi yang didiskusikan antara peserta dengan pemateri secara dialogis dengan mengedepankan pada pendekatan problem based learning. Materi-materi yang disampaiakan oleh Tim PPM merupakan kompilasi materi yang telah disusun 
berdasarkan pada aspek relevansi (kesesuaian) dengan problematika yang dihadapi. Secara spesifik, materi Kiat Menangkal Bahaya Hoax Dari Internet Terhadap Anak-Anak, disampaikan lebih menekankan untuk memberikan ruang dan kesempatan bagi peserta dalam memecahkan problematic yang sering dihadapi.

Setelah kegiatan pengabdian pada masyarakat ini dilaksanakan selama satu hari, kami selaku pelaksana melakukan wawancara terbuka kepada beberapa peserta pelatihan dan beberapa pengelola desa Rampung, untuk mengetahui pendapat dan masukan, dari hasil wawancara bahwa 90\% mereka sangat antusias mengikuti penyuluhan ini tema seperti ini merupakan hal baru yang belum pernah diikuti dalam penyuluhan-penyuluhan sebelumnya. Hasil pengabdian ini dapat menambah wawasan dan pengetahuan dalam menangkal bahaya hoak dari internet terhadap anak-anak.

Selama kegiatan pelatihan berlangsung, Tim PPM juga berupaya untuk melakukan monitoring untuk mengetahui secara jelas kelemahan atau kekurangan yang ada. Monitoring ini juga merupakan salah satu bentuk dari penjaminan mutu kegiatan pelatihan dan sebagai upaya memberikan garansi bagi peserta pelatihan terhadap fungsionalitas (kebermanfaatan) dari hasil pelatihan bagi penguatan kompetensi.

Khusus untuk sesi diskusi (tanya Jawab), banyak peserta pelatihan yang mengajukan pertanyaan penting terhadap penyampaian materi yang bersifat praktik. Peserta pelatihan terlihat antusias ketika tim PKM menyampaikan berbagai materi yang berkaitn dengan pelatihan pendidikan ini.

\section{Evaluasi Kegiatan}

Setelah penyampaian materi dan pelaksanaan kegiatan penyuluhan pendidikan, Tim PPM berupaya untuk melakukan evaluasi terhadap implementasi dari pelatihan yang diselenggarakan. Evaluasi ini bertujuan untuk mengetahui tingkat keberhasilan dari pelaksanaan kegiatan pelatihan yang dilakukan.

\section{a. Evaluasi Proses}

Evaluasi proses ini berupaya untuk mengetahui tingkat partisipasi, respon, dan pemahaman terhadap materi pelatihan yang disampaikan kepada peserta. Dari sisi partisipasi, yang ditargetkan mengikuti pelatihan ini adalah seluruh wali murid PAUD Darul Mukhsinin. Dalam kenyataannya, hampir semua peserta hadir dan ikut berpartisipasi aktif selama kegiatan pelatihan berlangsung. Kemudian, respon peserta terhadap kegiatan pelatihan ini menunjukkan dukungan yang positif dan memandang perlu untuk mengembangkan kegiatan sejenis yang dapat berkesinambungan.

b. Evaluasi Hasil (Produk)

Pada aspek evaluasi hasil (produk) pelatihan ini, Tim PPM berupaya untuk malakukan evaluasi terkait dengan tingkat pemahaman peserta pelatihan. Terkait dengan evaluasi hasil kegiatan pelatihan ini, Tim PPM berupaya melakukan observasi (pengamatan) secara cermat terhadap antusime peserta.

Indikator keberhasilan dari pelaksanaan kegiatan pelatihan ini antara lain:

1. Peserta pelatihan aktif (partisipatif) dan bekerjasama dengan baik selama mengikuti kegiatan, hal ini dapat terlihat dari tingkat kehadiran peserta, aktivitas diskusi dan tanya jawab antara peserta dan pemateri yang dialogis. Selain itu, peserta pelatihan kooperatif untuk dapat mendukung keterlaksanaan kegiatan pelatihan ini.

2. Peserta pelatihan memahami materimateri pelatihan, hal ini dapat diukur dari pencapaian kemampuan memahami materi-materi pelatihan oleh peserta yang berada dalam kategori cukup menguasai.

\section{Rencana Tindak Lanjut}

Kegiatan pengabdian pada masyarakat (PPM) ini tidak dilakukan secara parsial, artinya setelah selesai kegiatan, selesai pula seluruh aktivitasnya. Akan tetapi, pasca kegiatan pelatihan ini, Tim PPM akan terus berupaya untuk menindaklanjuti kegiatan yang telah dilaksanakan dengan mengidentifikasi kekurangan atau kelemahan Oleh karena itu, bentuk tindak lanjut yang 
akan dilakukan adalah dilaksanakannya kegiatan serupa dalam rangka memenuhi rasa keingin tahuan yang sangat besar dari peserta.

\section{SIMPULAN}

Penyuluhan tentang Kiat Menangkal Bahaya Hoax Dari Internet Terhadap AnakAnak memberikan dampak yang positif bagi pihak desa Rempung Kapupaten Lombok Tengah, bagi orang tua, dan masyarakat. Sehingga kedepannya perlu adanya kegiatan serupa terutama bagi wali murid dalam mendalami ilmu tentang menangkal bahaya Hoak dari internet.

\section{SARAN}

Setelah adanya kegiatan edukasi penyuluhan tentang menangkal bahaya Hoak dari internet terhadap anak-anak di desa Rempung, mampu menjadi mitra dalam mengembangkan pengetahuan masyarakat dan memajukan pendidikan.

\section{DAFTAR PUSTAKA}

Daryanto. 2003. Pengetahuan Dasar Ilmu Komputer. Rama Widya. Bandung.

Daryanto. 2004. Konsep Jaringan Komputer dan Pengembangan. Salemba. Infotek. Jakarta.

Jogiyanto. 2005. Analisis dan Desain Sistem Informasi. Yogyakarta: Andi Offset.

Lajamuddin, A. 2005. Analisis dan Desain Sistem Informasi. Yogyakarta: Graha Ilmu.

Nugroho, Endro. 2009. Buku Pintar Jaringan Komputer. Modeoms. Yogjakarta.

Papalia, D. E., \& Feldman, R. D.2014. Menyelami Perkembangan Manusia Edisi 12 Buku 1. Jakarta: Salemba Humanika.

Patmonedowo, S.2003. Pendidikan Anak Pra Sekolah. Bandung: Rineka Cipta.

Pratisti, W. D.2008. Psikologi Anak Usia Dini. Jakarta: PT Indeks. 